\title{
Renewable Energy Potential and Available Capacity for Wind and Solar Power in Morocco Towards 2030
}

\author{
Mohamed AZEROUAL*, Aboubakr EL MAKRINI, Hassan EL MOUSSAOUI and Hassane EL \\ MARKHI
}

The Signals, Systems and Components Laboratory, Sidi Mohamed Ben Abdellah University,FST Fez, Morocco

Received 10 October 2017; Accepted 20 February 2018

\begin{abstract}
In this paper, we identify the current status and outlook of the renewable energy source in Morocco. We provide also the challenges and the barriers to the development of renewable energy (RE) in Morocco and the national strategy for energy security and meeting these challenges. Then, using a time series method, we estimate the capacity of the wind and solar power in Morocco plans in the long-term towards 2030, that can be injected without creating the constraints of transit on the grid utility and on the whole electrical system.
\end{abstract}

Keywords:Renewable energy (RE), Wind power, Pumped Energy Storage (PES), Solar power, Available capacity, Load monotone.

\section{Introduction}

Nowadays the world is facing a double challenge in the energy area, the first challenge is the absence of a secure and adequate energy sources and the second is the environmental losses generated by excessive energy consumption and using the primary energy sources, such as oil and coal. The energetic development in the world oriented to the renewable energy development sector, due to the increasing of electricity demand, the industrial sector growth, and a high price of power conventional energy resources [1].

The geographical conditions of Morocco mean that it has large potential in terms of the wind, solar and hydropower [1]. In 2009, Morocco launched the national energy strategy, for renewable energy and energy efficiency plan as the main pillars. The strategic and general conditions in the country are oriented to the development of renewable energies. Energy projects in Morocco stand out big time with a bold target of sourcing more than $52 \%$ of its electrical energy from renewable sources by 2030 which 4560 MW solar, $4200 \mathrm{MW}$ wind, and $3100 \mathrm{MW}$ hydropower and plan to have $2000 \mathrm{MW}$ of wind, $2000 \mathrm{MW}$ of solar and $2000 \mathrm{MW}$ of hydropower plants by 2020 [2].

The increasing of the renewable energy installation has an increasing impact on the electrical grid due to the difficulty in forecasting production, the maximum capacity that can be injected into the grid, and a deterioration in the energy quality. In our case, we have estimated the maximal capacity for the renewable energy precisely solar and wind energy based on the load power of Morocco toward 2030, for this forecasting we are using the time series methods of forecasting. Excel and MATLAB will be used as aids for analysis.

Time series forecasting methods are the most current methods for forecasting and are useful when you are

\footnotetext{
*E-mail address: Mohamed.azerouall@usmba.ac.mo

ISSN: 1791-2377 @ 2018 Eastern Macedonia and Thrace Institute of Technology. All rights reserved. doi:10.25103/jestr.111.23
}

forecasting something that is changing over time [3], the time series decomposition is based on four segments: trend, cyclic, seasonal, and random components (section 6.2). The electrical load is principally a time series has generally three seasonal cycles: daily cycle (the daily load curve), a weekly cycle, and a yearly seasonal cycle [4]. In our case, we have applied the Time Series methods on energy consumption in Morocco between 2008 and 2016 for estimating the energy forecast in 2030. This paper provides a survey of the current status and outlook of the renewable energy in Morocco including solar, wind, hydroelectric, biomass, and geothermal energy and we have plotted the load power curve for estimate the available capacity of the wind and solar energy towards 2030 .

The paper is organized as follows. Section 2 presents the current situation of the energy, national energy strategy, and energy challenges in Morocco. Next, section 3 discusses the renewable energy potentials in Morocco. Section 4 introduces the energy efficiency. In section 5 , we introduce the barriers and solutions to the development of renewable energy in Morocco. The demand forecasting over 2030 is discussed in section 6. The available capacity of RE in Morocco towards 2030 that can be injected into the grid is presented in section 7. Finally, Section 8 presents conclusions.

\section{Current Situation of the Energy in Morocco}

As electricity demand increase with economic development, Morocco's current electricity demand grows strongly with an average rate of $6.5 \%$ per year. Consequently, electricity demand more than doubled from $16 \mathrm{TWh}$ (TeraWatt-hour) in 2002 to $34 \mathrm{TWh}$ in 2014. For this reason, the production of energy in Morocco increased by $6-7 \%$ per year between 2002 and 2012 to provide this demand grows. The total capacity installed in Morocco in 2015 it is $8154 \mathrm{MW}$, with $34 \%$ of renewable energies with the following mix: Carbon $(32 \%)$, natural gas $(11 \%)$, hydropower $(22 \%)$, fuel oil and 
diesel (24\%), solar (2\%) and wind power (10\%) (see Figure 1) [5] [6]. The industry sector is the highest consumer of electricity in Morocco with $43.6 \%$, the residential sector with $32.8 \%$ is the second consumer, and the commercial field with agriculture sector $(22.4 \%)$, while the transport sector accounts only for $1.2 \%$ of the electricity demand. According to Ministry of Energy, Mines, Water and the Environment (MEMEE) of Morocco [6] [7], future primary energy demand could reach 26 Mtoe (million tonnes of oil equivalent) in 2020 and 43 Mtoe in 2030. Also, Morocco imports electricity from the neighboring countries.

\section{$120,00 \%$}

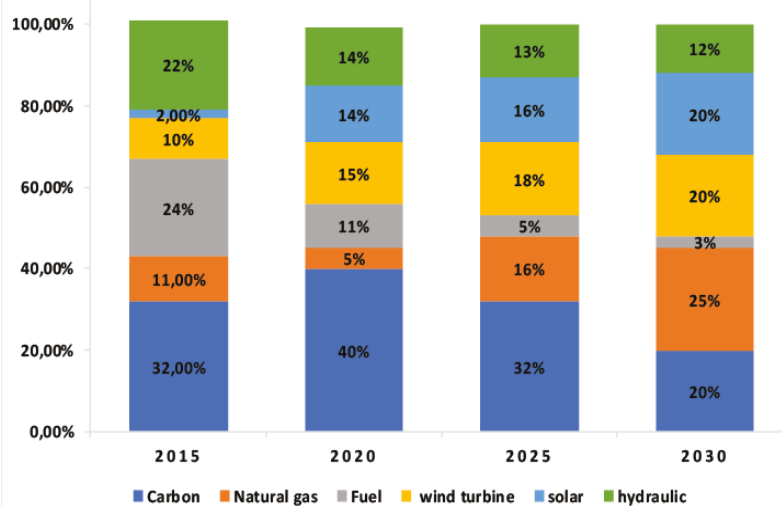

Fig. 1. Plan of the electricity sources from 2015 to 2030 [5].

\subsection{Energy challenges}

The power grid in Morocco is characterized by four principal challenges:

1. Increasing $\mathrm{CO} 2$ emissions: Despite the country's efforts to base its electricity system on high shares of renewable and green energy, its national energy consumption is still very controlled by fossil energy carriers. As a consequence, total $\mathrm{CO} 2$ emissions are anticipated to closely follow the rising energy demands and increase substantially in the mid-long term [8].

2. Electricity system stability: Morocco is in critical need of new electricity infrastructure with the electricity consumption projected to grow considerably. This growing demand required a substantial investment in additional power generation capacity, transmission, distribution, and storage infrastructure [9].

3. Electricity prices: Electricity prices in Morocco are not uniform. They are differentiated by voltage and consumer category. the pricing strategy using in the country does not take the user's socioeconomic status into account [10].

4. Energy import dependence: Unlike some of its neighbors in the north of Africa, Morocco is highly dependent on imported hydrocarbon energy. With very limited local energy sources, over $96 \%$ of its energy supplies come from outside: oil principally from Saudi Arabia, gas almost exclusively from Algeria, and coal from Russia and South Africa [10].

\subsection{Morocco's National Energy Strategy (NES)}

Morocco adopted its National Energy Strategy (NES) with corresponding targets for 2020 in 2009 and renewed it in Paris end of 2015 with targets until 2030. Challenging the three principal challenges of modern energy policy, security of supply, affordability, and sustainability.

The NES focuses on four main goals [10]:

- Securing energy supply, especially by reducing the dependence on imported energy carriers through the development of RE sources (from 96\% in 2015 to $82 \%$ by 2030 ) and the increased exploration of conventional energy sources.

- Controlling energy demand, notably by improving energy efficiency.

- Generalizing energy access to all segments of the population at affordable and competitive prices.

- Conserving the environment.

Based on these goals, the NES and the related National Priority Action Plan (PNAP, 2009/2015) set the following targets:

1. Electricity supply: Increase the total installed capacity of renewable energy in the electricity sector to $42 \%$ by 2020 and to $52 \%$ by 2030 (up from $34 \%$ in 2015 ).

2. The demand for energy: Around $10-12 \%$ of the primary energy demand of the country by 2020 and 15 $20 \%$ by 2030 with renewable energy sources (solar, wind, and hydroelectric).

3. Energy Efficiency: Achieve $12 \%$ energy saving by 2020 and $15 \%$ by 2030 as well as to reduce greenhouse gas emissions in the transport sector by $35 \%$.

\subsection{Regulatory framework regarding the electricity} sector

Morocco is an innovative country in the development of RE in the Middle East and North Africa (MENA) region. Law $\mathrm{n}^{\circ} 13-09$ on renewable energy [11] provides a legal framework for the development of RE projects in Morocco and sets the framework for private investments in this sector. It introduces major innovations, including the opportunity for a competition of renewable electricity production and the capacity to export electricity from renewable sources, by using the national grid. It also sets an authorization/declaration system, depending on the capacity of the facility as follows:

- An authorization regime for renewable energy projects with a capacity of $2 \mathrm{MW}$ or more.

- A declaration is required if an electricity generating facility capacity is between $20 \mathrm{~kW}$ and $2 \mathrm{MW}$.

- In respect of facilities that produce thermal energy, there is only a declaration if the capacity is equal to or higher than $8 \mathrm{MW}$.

- An obligation imposed on the administrative government responsible for the development of $\mathrm{RE}$ projects to allocate areas designed for the construction of wind and solar for producing the high capacity possible.

\subsection{Interconnection capacity with neighboring} countries

The interconnections with neighboring countries available give guarantees the reliability of supply and the security, contributing stability to both systems as a whole and also these interconnections can increase the maximal capacity of solar power (Section 7). In addition, it develops the technical 
and economic exploitation of the energy generation and transmission systems of both countries. Currently, Morocco has two interconnections with Spain and Algeria. These interconnections will be reinforced by doubling the capacity of new lines and the others interconnections with Portugal and Mauritania is under study. Strengthening and development of energy interconnections with neighboring countries are shown in Figure 2 [12].

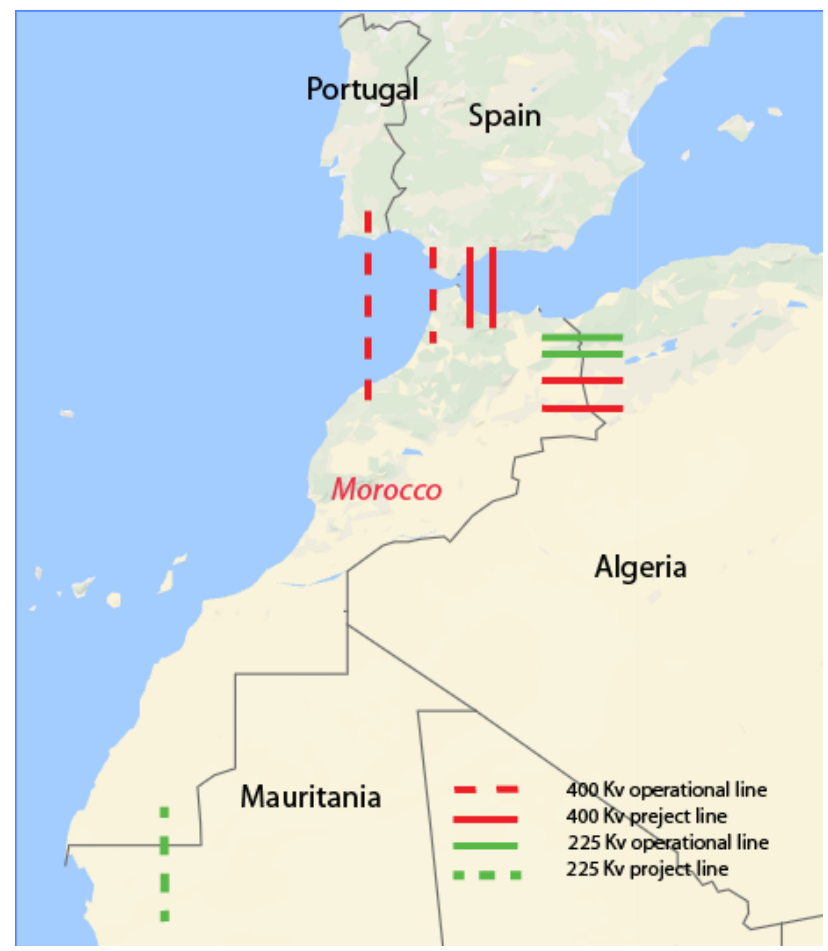

Fig. 2. Strengthening and development of energy interconnection with neighboring countries [12].

\subsubsection{Interconnection between Morocco and Spain}

The capacity of the existing interconnection between Morocco and Spain is $1400 \mathrm{MW}$ [5]. A new interconnection submarine with Spain of 700MW for guarantees the security and reliability of supply, contributing stability to both systems as a whole [13].

\subsubsection{Interconnection between Morocco - Algeria}

The first electrical interconnection between Morocco and Algeria of $225 \mathrm{KV}$ was commissioned in 1988 with a capacity of $200 \mathrm{MW}$ [14]. The installation of a second line and then a third, commissioned in 2009. The capacity of the exchange has been increased to $300 \mathrm{MW}$, with new $400 \mathrm{KV}$ double line between Sid Ali Boussidi (Algeria) -Bourdim (Morocco) [1].

\subsubsection{Interconnection between Morocco - Portugal}

The study for the project begins in 2016 to build an interconnection with a capacity of $1000 \mathrm{MW}$ [15], this first interconnection, which will help the two countries to exchange electricity. The project will also inject electricity from renewable sources.

\subsubsection{Interconnection between Morocco - Mauritania} This interconnection has some objectives [2]:

- Enhance the renewable energy development in the region.

- Linking the European and African west electrical network through the interconnection Morocco-Spain.

\subsection{National electricity transmission}

The National Office of Electricity and Water (ONEE) is in charge of the public service, electric energy generation, transmission, and supply. The electricity transmission network of Morocco constituted by $2,765 \mathrm{~km}$ of $400 \mathrm{KV}$ lines, nearly $9,680 \mathrm{~km}$ of $225 \mathrm{KV}$ lines, $147 \mathrm{~km}$ of $150 \mathrm{KV}$ lines and about $12,000 \mathrm{~km}$ of $60 \mathrm{KV}$ lines [16]. ONEE launched an important program to increase its transmission networks and electricity supply. This program is constituted by realization $980 \mathrm{~km}$ of $400 \mathrm{KV}, 1292 \mathrm{~km}$ of $225 \mathrm{KV}$, and $382 \mathrm{~km}$ of $60 \mathrm{KV}$.

\section{Renewable energy potentials in Morocco}

Morocco is ready to lead the Middle East and North Africa (MENA) region in the renewable energy sector. The limitation of conventional hydrocarbon resources, high energy import from other countries to satisfy its demand for energy, the Moroccan government historically resorted to fossil fuel importation and rapidly rising electricity demand have provided Morocco with the impetus to increase the RE development and appear as a stable target for power sector investment [16]. To resolve its energy challenges, the kingdom of Morocco is turning to renewable energy development, comprising the wind, solar and hydro. Morocco has the most ambitious renewable energy targets in the MENA region, pledging to increase the energy from renewable source to $42 \%$ of the country's electricityproducing by 2020 and $52 \%$ by 2030 , evenly separated between the wind, solar and hydro as shown in Table 1 [17] [18].

Table 1. Official Moroccan renewable energy targets for 2020 and 2030 [18] [19].

\begin{tabular}{c|c|c|c|c}
\hline $\begin{array}{c}\text { Renewabl } \\
\text { e energies }\end{array}$ & $\begin{array}{c}\text { Installatio } \\
\text { n target } \\
\text { for 2020 }\end{array}$ & $\begin{array}{c}\text { Percent } \\
\text { of } \\
\text { capacit } \\
\text { y for } \\
\text { 2020 }\end{array}$ & $\begin{array}{c}\text { Installatio } \\
\text { n target } \\
\text { for 2030 }\end{array}$ & $\begin{array}{c}\text { Percent } \\
\text { of } \\
\text { capacit } \\
\text { y for } \\
\mathbf{2 0 3 0}\end{array}$ \\
\hline Wind & $2000 \mathrm{MW}$ & $14 \%$ & $4200 \mathrm{MW}$ & $20 \%$ \\
Solar & $2000 \mathrm{MW}$ & $14 \%$ & $4560 \mathrm{MW}$ & $20 \%$ \\
Hydro & $2000 \mathrm{MW}$ & $14 \%$ & $3100 \mathrm{MW}$ & $12 \%$ \\
\hline
\end{tabular}

\subsection{Wind energy status and outlook}

Some of the greatest wind sources in the world are found in Morocco, with $3500 \mathrm{~km}$ of coastline and wind speeds up to $11.5 \mathrm{~m} / \mathrm{s}$ at a height of $80 \mathrm{~m}$, the total wind power potential in Morocco is estimated at about 25 GW [19]. Morocco's total installed wind power capacity at the end of 2016 was 803 MW [18] as shown below in Table 2 [20].

Table 2. Total installed wind power capacity at the end of 2016 [20].

\begin{tabular}{c|c}
\hline Site & Power in MW \\
\hline Akhefnir 1 Tan-Tan & 100 \\
Am ogdul Essaouira & 60 \\
Fouma Alouad Laayoune & 50 \\
Lafarge Tetouan & 32 \\
Tanger 1 & 140 \\
Tarfaya & 301 \\
Haouma Tangier & 50 \\
A. Torres Tetouan & 50 \\
Ynna Bio Power Essaouira & 20 \\
\hline
\end{tabular}


The developing importance to exploit wind energy has driven Morocco stakeholders to the realization of important wind farms (see Figure 3 [21]). The first wind farm in Morocco was Abdelkhalek Torres with a capacity of 50.4
MW, currently producing about $200 \mathrm{GW}$ h/year. Other wind farms are in Essaouira (60 MW) operating ago April 2007, Tangier I with $140 \mathrm{MW}$, Tetouan with $300 \mathrm{MW}$, etc.

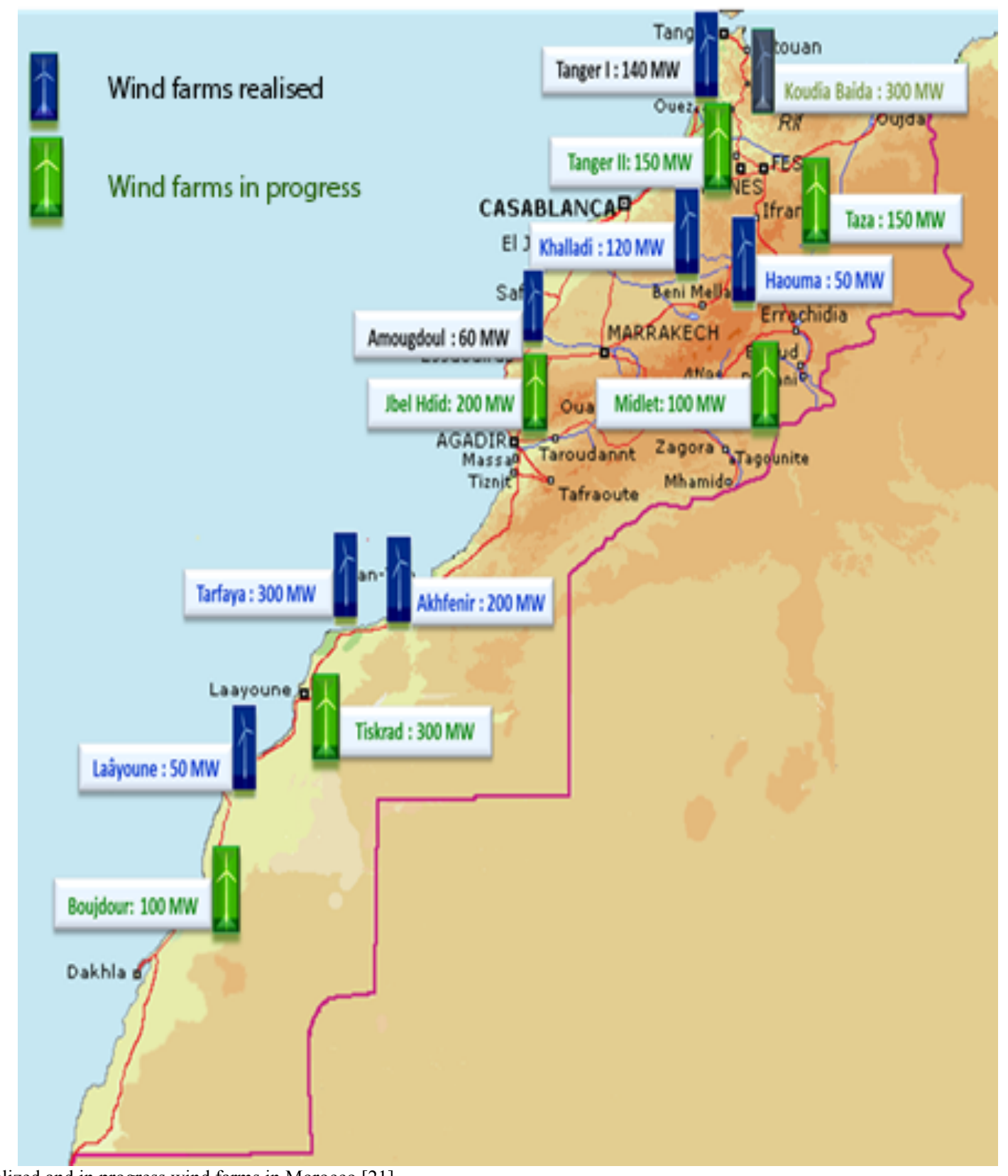

Fig. 3. Realized and in progress wind farms in Morocco [21].

Morocco needs to achieve its 2000 MW target of 2020 and $4200 \mathrm{MW}$ by 2030 [2] [12]. The kingdom planning to develop large wind farms (see Figure 3 ) to achieve $20 \%$ of wind power in 2030. The increase of wind power capacity will then sit some challenges to the stability of the electricity system. Therefore, it is necessary to determine the available capacity of the wind that can be injected into the grid.

The wind energy project development in Morocco increases, ONEE has six wind farms under construction toward 2020 and other farms to 2030 with a total capacity of $1000 \mathrm{MW}$ in Tangier II $150 \mathrm{MW}$, Midelt $100 \mathrm{MW}$, Jbel Lahdid $200 \mathrm{MW}$, Tiskrad $300 \mathrm{MW}$, Boujdour $100 \mathrm{MW}$, and Taza 150MW. The investments amounting to around 3.5 billion US dollars are planned between 2015 and 2020 under the wind power plan [20].
The developments in wind power are very increasing currently. The company Siemens, which has been serving in Morocco since 1929, has completed a 300 MW project in Tarfaya. It also just declared the construction of a factory in Tangier to produce rotor blades for markets in Africa, Europe, and the Middle East. Total investment in this project amounts to about 120 million US dollars [20]. Another promising sign is that in early 2016 the Nareva/Enel/Siemens consortium was the successful tenderer in the appropriation process for an $850 \mathrm{MW}$ wind power project with a world-record low price (0.03 US dollars/kWh).

\subsection{Solar energy status and outlook}

Similar to wind energy, solar energy depends on weather conditions. Variations in the weather such as clouds and 
pollution could affect solar power production. The solar energy is available just during sunlight hours. Therefore, solar power generation changes by season, location, and time of the day.

Many technologies are used to expand solar radiation, including thermal solar energy, concentrated solar power plant (CSP), solar chimneys or powers, and photovoltaic systems. An advantage of photovoltaic technology compared to other technologies is the possibility to integrate a PV collector into the building by turning outside walls, windows, and roofs into a PV collector.
CSP technologies mean plants that produce electrical energy by means of concentrated sun irradiation. Generally, CSP plants use large-area mirrors to concentrate sunlight onto a relatively small-aperture receiver. Due to its geographical location, Morocco is one of the important solar potentials in the world that is estimated as of over 5 $\mathrm{kWh} / \mathrm{m}^{2} /$ day (see Figure 4 [22]). For increasing the capacity of the production, the kingdom of Morocco has a stated goal for solar energy terms of Concentrating Solar Power (CSP) and Photovoltaic (PV) of 14\% (2000 MW) by 2020 and $20 \%$ (4560 MW) by 2030 of the country's production capacity [21].

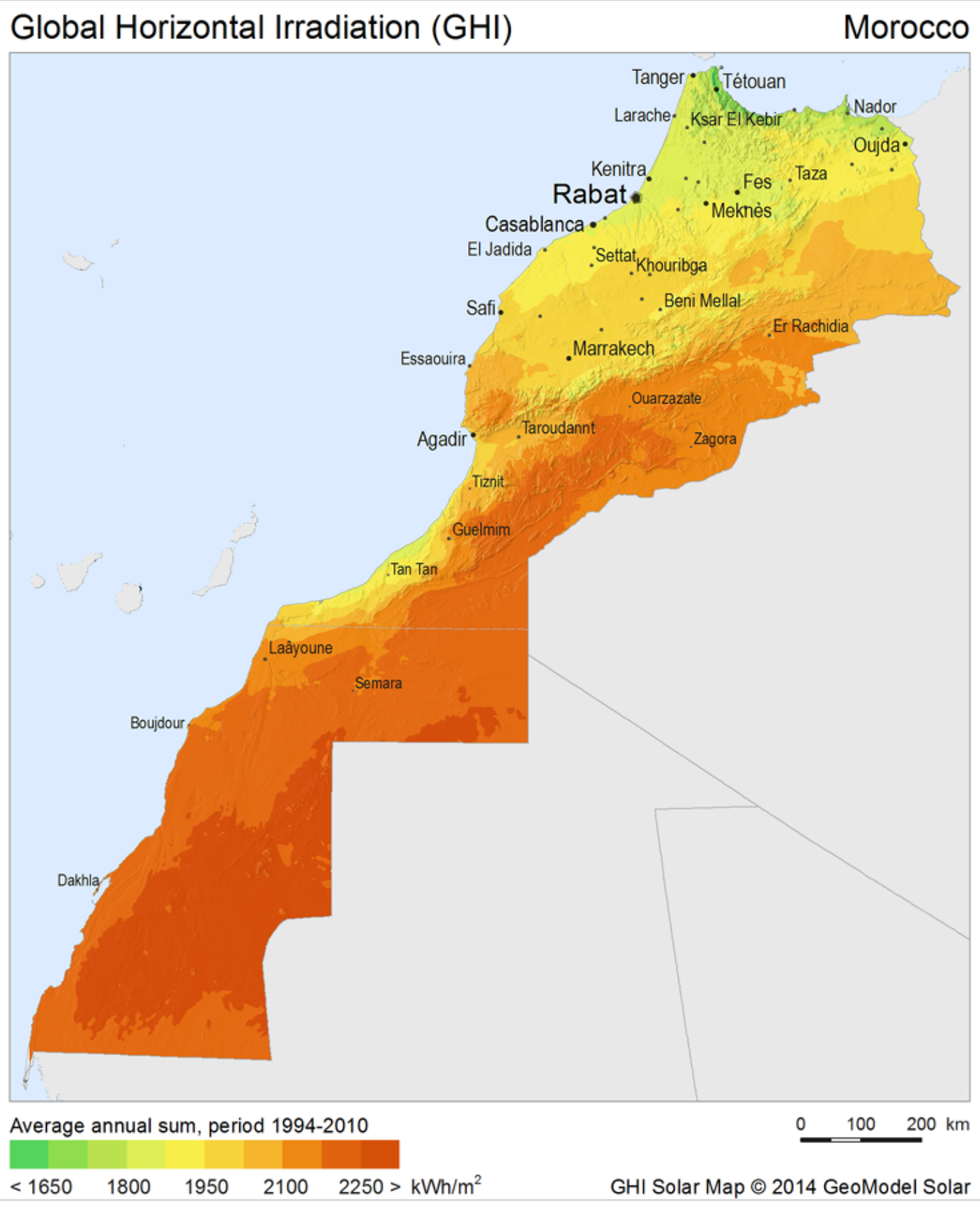

Fig. 4. Moroccan solar potential [22].

Morocco's total installed solar power capacity constituted only by CSP technology at the end of 2016 [12] was $180 \mathrm{MW}, 160 \mathrm{MW}$ Ouarzazate Noor I project, which is currently under service and $20 \mathrm{MW}$ solar thermal CPS and gas - Ain Bni Mathar [23]. Similarly, to wind, the kingdom aims to increase installed capacity of CSP and PV solar production to at least $2000 \mathrm{MW}$ by 2020 and $4560 \mathrm{MW}$ by 2030 [12]. Moroccan Agency for Solar Energy (MASEN) is the responsible for many aspects of solar (CSP and PV) energy in the country and also ONEE is itself planning to 
create a number of medium-sized PV [14]. Table 3 [18] shows the solar stations under service or are under development, four stations in Ouarzazate with the capacity around to $570 \mathrm{MW}$, Midelt $400 \mathrm{MW}$, Tata $400 \mathrm{MW}$, Boujdour $80 \mathrm{MW}, 200 \mathrm{MW}$ in Noor Atlas, Noor Tafilalt station generated $100 \mathrm{MW}$.

Table 3. The solar stations under service or are under development in Morocco [18].

\begin{tabular}{|c|c|c|c|}
\hline $\begin{array}{c}\text { Site/power } \\
\text { plant }\end{array}$ & $\begin{array}{l}\text { Power } \\
\text { in MW }\end{array}$ & Technology & State \\
\hline $\begin{array}{l}\text { NOORo I } \\
\text { Ouarzazate }\end{array}$ & 160 & CSP & Under service \\
\hline $\begin{array}{l}\text { NOORo II } \\
\text { Ouarzazate }\end{array}$ & 200 & CSP & $\begin{array}{c}\text { Under } \\
\text { development }\end{array}$ \\
\hline $\begin{array}{l}\text { NOORo III } \\
\text { Ouarzazate }\end{array}$ & 150 & CSP & $\begin{array}{c}\text { Under } \\
\text { development }\end{array}$ \\
\hline $\begin{array}{l}\text { NOORo IV } \\
\text { Ouarzazate }\end{array}$ & 70 & PV & $\begin{array}{c}\text { Under } \\
\text { develonment }\end{array}$ \\
\hline Midelt & 400 & CSP and PV & $\begin{array}{c}\text { Under } \\
\text { development }\end{array}$ \\
\hline Tata & 400 & CPS and PV & $\begin{array}{c}\text { Under } \\
\text { development }\end{array}$ \\
\hline $\begin{array}{l}\text { Ain Beni } \\
\text { Mathar }\end{array}$ & 20 & CPS and gas & Under service \\
\hline $\begin{array}{l}\text { Noor B } \\
\text { Bouidour }\end{array}$ & 80 & PV & $\begin{array}{c}\text { Under } \\
\text { develonment }\end{array}$ \\
\hline $\begin{array}{l}\text { Noor L } \\
\text { Laayoune }\end{array}$ & 20 & PV & $\begin{array}{c}\text { Under } \\
\text { development }\end{array}$ \\
\hline Noor Tafilalt & $75-100$ & PV & $\begin{array}{c}\text { Under } \\
\text { development }\end{array}$ \\
\hline Noor Atlas & 200 & PV & $\begin{array}{c}\text { Under } \\
\text { development }\end{array}$ \\
\hline Noor Argana & 100 & PV & $\begin{array}{c}\text { Under } \\
\text { development }\end{array}$ \\
\hline
\end{tabular}

\subsection{Hydroelectricity}

Morocco's installation of hydropower production capacity started in the 1960s. This capacity increased in each year, currently, Morocco has 26 traditional stations of hydropower with the capacity of $1360 \mathrm{MW}$ and $464 \mathrm{MW}$ from a pumped energy storage (PES) in Afourer. Hydropower can be considered a traditional element of Morocco's feet of power plants (installed capacity in 2015 stood at 1,770 MW), and its potential is well employed. ONEE is generally the responsibility for constructing Hydroelectricity projects. For achieving their goal of $2000 \mathrm{MW}$ by 2020 , ONEE intends to construct new PES of $350 \mathrm{MW}$ at the site of Abdelmoumen that will increase the capacity to $2120 \mathrm{MW}$ [23] and others PESs projects under study for increasing the maximal capacity of wind power (Section 7).

\subsection{Biomass energy}

Morocco's large agricultural sector and the fact that a large part of the waste generated is made up of organic components are a boon to power generation from biomass and biogas [24]. In Morocco, especially in rural regions, there is an important quantity of forest residues and crop.

This has helped the country to advance a promising alternative source of renewable energy, which consists of biomass energy. Biomass is an organic substance such as crops, wood, and animal wastes that can be used as an energy source. The objectives of Morocco are to strengthen the biomass area, with a way to replacing fuel oil in the industrial field. However, there are no national strategies in place at present to tap into this potential, although some small companies have previously initiated progress in this field [25].

\subsection{Geothermal energy}

Geothermal is energy available as energy included in or delivered from the earth's crust [26]. In Morocco, there are several important areas where the geothermal energy could be more used for greenhouses, aquacultures, heat pumps, etc. The use of geothermal energy will help Morocco to produce sufficient food for its domestic market, as well as for export. The current situation of geothermal energy in Morocco estimated by 5.02 MWt (MegaWatt thermal) and $22 \mathrm{GW} \mathrm{h} /$ year as the annual using for bathing and swimming, others applications like electricity production [21] [27].

\section{Energy efficiency}

The national strategy of Morocco adopted in 2009 considers that the energy efficiency (EE) as a national priority to achieve $12 \%$ energy savings by 2020 and $15 \%$ by 2030 [25]. In this context, the energy efficiency plans have been included in all key divisions, including transport, industry, and building.

Morocco Agency of Renewable Energies and Energy Efficiency (ADEREE) has launched several projects of energy efficiency in the building, industry, and transport sectors, which represent more than $90 \%$ of Moroccan energy consumption.

\section{Barriers and solutions to the development of renewable energy in Morocco}

In this section, we will present the various challenges that limited the development of renewable energies in Morocco [28] [29] [19]:

i. Economics and financial barriers: Renewable power technologies have high investment costs, but low operating costs opposed to fossil alternatives, as they have no fuel costs (excluding biomass power). Investment costs are generally higher in developing than in developed countries due to factors such as poorly trained labor forces, a requirement to bring engineers from outside, and weak transportation infrastructure, a lack of accessible financial support for small-scale projects, and also the high initial capital.

ii. Political, institutional and regulatory barriers: The introduction and success in the use of the renewable energy technology and energy efficiency measure highly depend on the existing policy framework in each country. In Morocco, the absence of cooperation synergetic collaboration between the various stakeholders and lack of coordination between the political groups and ministries (distribution operators are often against the development of RE in their electrical grid).

iii. Technical barriers: Continuing major technical issues related to the intermittent and the variability nature of renewable energies [30], one of the main obstacles to the development of renewable energies is the intermittency of these 
sources. Indeed, renewable energies depend directly on primary energy fluctuations in nature: the wind turbine depends on the wind, which undergoes periodic interruptions sometimes, the solar depends on the sun that is available only during the day. The variability of renewable energy sources has always been present in the generation of electricity. Indeed, the availability of the resource from which renewable energies are exploited corresponds to the natural cycle of each resource.

Morocco has firmly set its displays on the large-scale renewable energy sources development. Nevertheless, important challenges and barriers still need to be addressed in order to unlock the full development potential of a sustainable electricity system. The following recommendations are provided to shed light on different aspects that should be improved to arrive at an integrated and coherent in development of RE in Morocco [29] [19]:

- Improve the sectoral interplay between and within relevant governmental institutions to jointly work for RE by promoting transparency and collaboration as well as minimizing institutional fragmentation.

- Increase absorptive capacities and R\&D (Recherche and Development) in RE deployment: research and development are an important component of longterm mastery of technologies, the development of know-how and the improvement of renewable energy performance. The development of sustainable RE programs in Morocco require a critical mass of $R \& D$ and combining between the major operators (utilities, industries) and research centers. For increasing the development of renewable energy sector, four principal dedicated state agencies have been created [28] [19]:

- The Institute for Research into Solar and New Energies (IRESEN) [31] was established in 2011 to support the national strategy and translate it into R\&D projects and cooperates with international partners from France, Germany, and Spain.

- The Moroccan Agency for Solar Energy (MASEN) [32]: It has three main responsibilities: a) Developing solar and other RE power projects, b) Contributing to the development of national expertise, and c) Proposing regional and national plans on solar and other RE technologies.

- The National Agency for Renewable Energies and Energy Efficiency (ADEREE) [33], develops national, regional, and sectoral plans with regard to REs and energy efficiency.

- The state-funded Energy Investment Company (SIE) [34]: According to its own mission statement, the company facilitates and develops projects in the energy sector with the support of partner investors, developers, and private industry.

- The decentralized production injection has a significant impact on the medium voltage grid operation. This affects first the distribution grid manager, as he is responsible for managing a reasonable level of reliability, quality, and safety. The grid manager has an increased need for observability via power grid tools (smart grid).
- Increase the role of universities and its researchers of transferring international knowledge for increasing the development of RE.

\section{Demand forecasting over 2030}

The electricity demand in Morocco is predictable to increase at a sustained rate over the next few years. This growing need for electricity is driven primarily by Morocco's increasing wealth and industry. In this section, we make an estimate of the electricity demand in Morocco between 2017 and 2030. For that, we applied the Time Series methods [35] on energy consumption in Morocco between 2008 and 2016 for estimating the energy forecast between 2017- 2030. There are several methods of forecasting, it's based solely on historical values for making the forecasts of the future.

\subsection{Characteristics of energy consumption in Morocco}

The power consumption is characterized by three cycles of time:

- The annual cycle: The annual peak of the year 2016 was recorded on July 20.

- Weekly cycle: Stable consumption on all days and significantly decreasing at the weekend.

- The daily cycle is characterized by three types: the full time starting at $7 \mathrm{~h}$, peak hour (at 12 o'clock), an evening peak (around $8 \mathrm{pm}$ ), and off-peak hour corresponding to the hours of sleep with a minimum consumption (from $23 \mathrm{~h}$ to $6 \mathrm{~h}$ ).

\subsection{Components of time series}

The analysis of time series presents a body of techniques to completely understand a data set. We can decompose the time series into 4 parts:

- The trend is the increment or a reduction in the series over a long period of time. Also known as the long-term trend.

- The cyclical fluctuation is the undulating up and down variations about the trend that is attributable to business or market conditions.

- The seasonality in a time series is the variation that happens each month, each year, etc. Seasonal variations tend to be reproduced from year to year.

- The residual effect is what leftovers having, removed the Trend, Cyclical and Seasonal elements of a time series. It represents the random error effect of a time series, created by events as widespread as wars, hurricanes, strikes, and randomness of human actions.

The time series models are an equation specifying how the components articulate with each other to form the time series. There are two classic models for time series forecasting decomposition based on trend as well as seasonality: The additive model and multiplicative models.

\subsubsection{The additive model}

The additive model is an implicitly assumed of the different components affected on the time series additively. We consider that the seasonal effect, trend, cyclical, and residual 
are independent. Graphically, the amplitude of the variations is constant around the trend.

$$
\begin{aligned}
& \text { Data }=\text { Seasonaleffect }+ \text { Trend }+ \text { Cyclical } \\
& + \text { Residual }
\end{aligned}
$$

\subsubsection{Multiplicative models}

For the Multiplicative models, the different components depending on the trend. Graphically, the amplitude of the seasonal variations fluctuates with a tendency is increasing and we consider that it is written in the following way:

Data

$=$ Seasonaleffect $*$ Trend $*$ Cyclical

* Residual

The time series method is performed in four steps:

- $\quad$ Determine the seasonal multipliers.

- Seasonally adjusting of the data.

- Determining the tendency equation.

- Calculate forecasts for future periods.

Before the decomposition of the series, it is necessary the presentation graphically of the phenomenon for description and to choose the model of the series. Based on the energy consumption data of Morocco from 2008 to 2016, we have plotted the curve showing the evolution of the consumption during this period (see Figure 5). We found that the amplitude of energy consumption increasing, for this reason, the multiplicative model using in this forecasting.

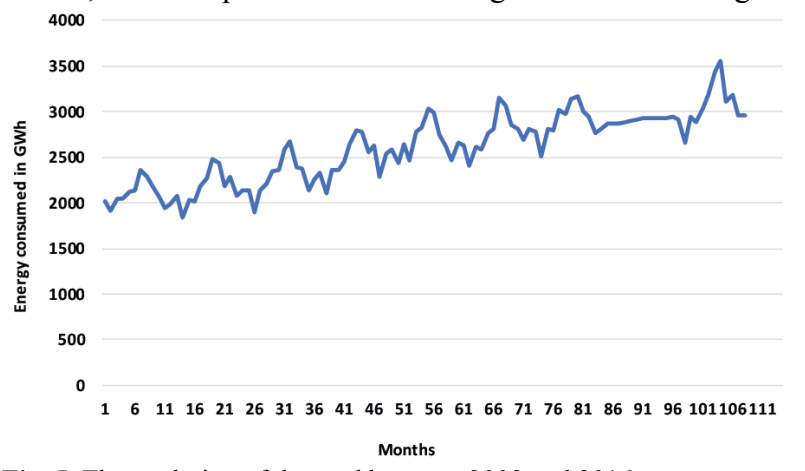

Fig. 5. The evolution of demand between 2008 and 2016.

Table 4 shows the results obtained for forecasting of electricity demand by 2030 in Morocco. The study of the annual electric consumption or demand uses a graph called the load monotone or power monotone, which gives the position of each power with 8784 hours of the year.

Table 4. The forecast of demand for the year 2030.

\begin{tabular}{c|c}
\hline Month of year 2030 & Energy forecast GWh \\
\hline January & 4706,309498 \\
February & 4318,294367 \\
March & 4713,309986 \\
April & 4661,814878 \\
May & 4946,962709 \\
June & 5058,241472 \\
July & 5421,652559 \\
August & 541,950193 \\
September & 4972,951514 \\
October & 4973,540362 \\
November & 4612,082422 \\
December & 4775,000596 \\
\hline
\end{tabular}

We have converted the obtained values into hourly powers, bearing in mind type of day, hourly and seasonal variations and we plotted the power monotone for 2030 in Morocco as shown in Figure 6.

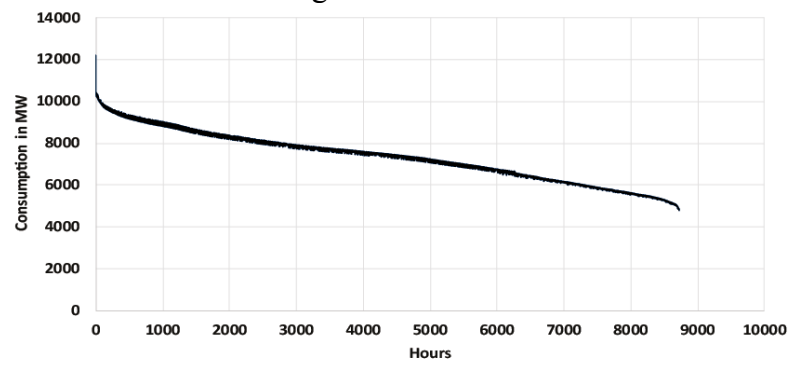

Fig. 6. Monotonic of the load for the year 2030.

The peak will exceed $12300 \mathrm{MW}$ in 2030 and the offpeak will be $4912 \mathrm{MW}$. This is indeed justified by the economic and industrial increase that Morocco will experience through these years, as well as the change in the way of life of Moroccans. With the monotonic of the load curve, we can estimate the maximum capacity of renewable energy to be injected into the grid.

\section{Available capacity of renewable energy in 2030}

The available capacity of renewable energy is the maximum capacity of the wind and solar energy that can be injected into the grid without creating the constraints of transit on the lines and the electrical system in general. The production of energy in Morocco is mixing between the renewable energy and the thermal power production. At each instant $t$, the electricity demand must be greater than or equal to the sum of the production sources:

$\mathrm{D}(\mathrm{t})$

$\geq P_{\min , T}$

$+\mathrm{P}_{\mathrm{RE}}(\mathrm{t})$

D: demand at instant t.

$\mathrm{P}_{\mathrm{RE}}$ : Renewable energy production.

$\mathrm{P}_{\min , \mathrm{T}}$ : Minimum thermal power.

For increasing the capacity of renewable energy, it is necessary to reduce the thermal production to the minimum possible value.

\subsection{Wind power capacity without PESs}

The wind power capacity is the difference between the minimum consumption peak and the sum of the minimum thermal power, this minimum point coinciding with the offpeak hours when the wind generation is at a maximum. The sum of the minimum thermal powers which cannot be stopped is $2240 \mathrm{MW}$, constituted by five sources: Jrada, Jadida, Safi, JLEC, and Mohammedia.

$$
\begin{aligned}
& D_{\text {min }}(t) \\
& \geq P_{\text {min }, T} \\
& +P_{\text {Wind,max }}(t)
\end{aligned}
$$

According to equation 4 , the available capacity of wind power is $2672 \mathrm{MW}$ without using the PESs as shown in Figure 7. 


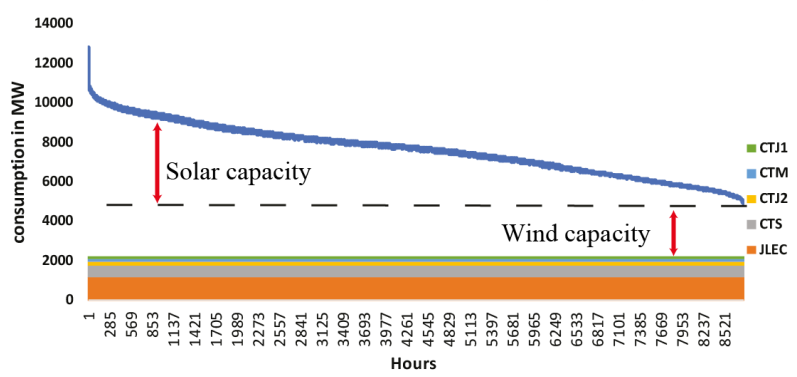

Fig. 7. Solar and wind capacity.

\subsection{Wind power capacity with PESs effect}

Pumped energy storages [36] are widely used to store electrical energy, and use for help to avoid energy waste during off-peak hours (night, weekend) and to compensate for the intermittent power generation in the wind and solar. The principle of PES is pumping to store energy and turbine to generate electricity.

The PESs has an important influence on the load monotone curve and increase the capacity of wind power, when the electricity demand is low (off peak between $23 \mathrm{~h}$ to $07 \mathrm{~h}$ ), the excess energy available is used to pump water and then at high consumption (see Figure 8 [2]), the PESs pump then becomes turbine and restores the energy accumulated previously.

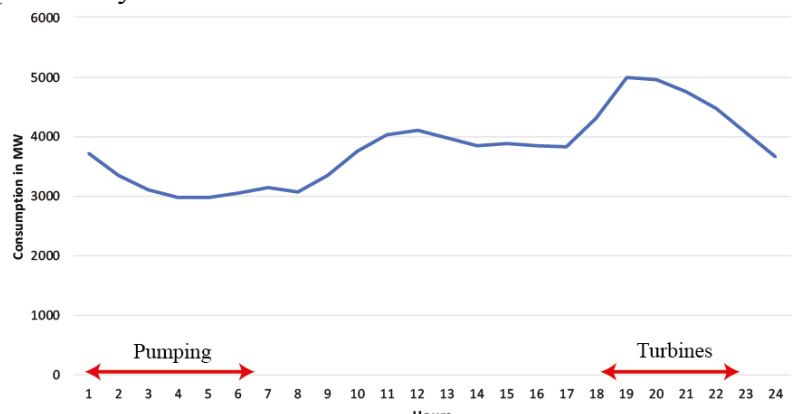

Fig. 8. PES operation time.

At present Morocco, has only one PES, and starts the detailed studies for others PESs, with a total power of 1415 MW (see Table 5) for adapted to the intermittency of renewable energy and increasing the capacity [2].

Table 5. Total PESs capacity forecast for 2030 [2].

\begin{tabular}{c|c}
\hline Park & Capacity in MW \\
\hline Afourer & 464 \\
I Fahsa & 350 \\
Abd Elmoumen & 300 \\
Megouto & 300 \\
Total & 1415 \\
\hline
\end{tabular}

Figure 9 presents the monotonic of power with PESs effect, the minimum load peak (wind power capacity) increased by $1415 \mathrm{MW}$, which corresponds to the pumping power of the PESs and the solar capacity decreased. The available capacity of wind energy that can be injected into the electrical network of Morocco in 2030 increase to 4087 MW, almost the target value to achieve in 2030 (4200 MW). PESs are to play an important role to increase the massive integration of wind energy (see Figure 10).

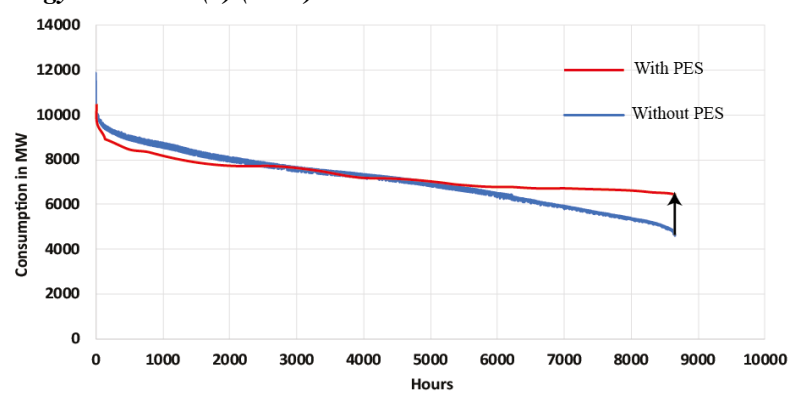

Fig. 9. Monotonic of the load with PES effect.

\subsection{Solar power capacity}

The solar production is maximum at around noon. Available capacity of solar energy is estimated by the equation 5 .

$$
\begin{aligned}
& D_{\text {max }}(t) \\
& \geq P_{\text {min } ; T}+P_{\text {Wind } ; \max }(t) \\
& +P_{\text {Solar } ; \max }(t)
\end{aligned}
$$

According to equation 5, the available capacity of solar power is $4353 \mathrm{MW}$ as shown in figure 6, this value decreased with the PESs effect to 2713MW (see Figure 10). The interconnection with other countries strengthens the capacity of solar energy. Indeed, the surplus of solar production can be absorbed by the neighboring countries since this overproduction coincides relatively with their peaks in demand of Spain [8] and Portugal. The capacity of interconnection with Spain and Portugal is about 2000 MW. These interconnections can be increasing the available capacity of solar energy to $4713 \mathrm{MW}$, almost the target value to achieve in 2030 (4560 MW).

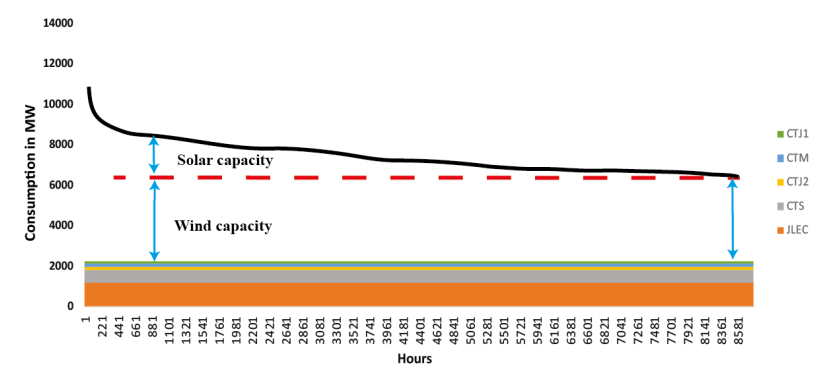

Fig. 10. Available capacity with PESs effect.

\section{Conclusion}

Morocco has an exceptional potential in RE, particularly in solar and wind energy. Morocco is well positioned to reach the $52 \%$ target in terms of installed electricity capacity from renewable sources in 2030, including 4560MW of solar energy, $4200 \mathrm{MW}$ of wind power and $1330 \mathrm{MW}$ of hydroelectric power. The results of the forecast show that the energy consumption is growing continuously between 2016 to 2030. This forecast allowed us to estimate the available capacity of wind energy which is $4087 \mathrm{MW}$ and the available capacity of solar energy which is $4713 \mathrm{MW}$ towards 2030 .

This is an Open Access article distributed under the terms of the Creative Commons Attribution Licence 


\section{References}

1. T. Kousksou, P. Bruel, A. Jamil, T. El Rhafiki, \& Y. Zeraouli. 'Energy storage: Applications and challenges. Solar Energy Materials and Solar Cells', 120, 59-80, 2014.

2. Presentation by Brahim Oumounah. 'Intégration des énergies renouvelables dans les systèmes électriques nationaux'. ONEECOP22, http://www.oneecop22.ma, 2016.

3. E. Almeshaiei, \& H. Soltan. 'A methodology for electric power load

forecasting'. Alexandria Engineering Journal, 50(2), 137-144, 2011.

4. H. Hahn, S. Meyer-Nieberg, \& S. Pickl. 'Electric load forecasting methods: Tools for decision making'. European Journal of Operational Research, 199(3), 902-907, 2009.

5. National Office of Electricity and Water (ONEE), http://www.one.org.ma/, 2015.

6. Ministry of Energy, Mines, Water and the Environment (MEMEE),

Grandes lignes de la stratégie énergétique 2020 et 2030. Dossier

de Presse

July 21, 2008.

7. Apricum GmbH, Morocco: The Western Gateway to MENAs Renewable

Energy Market. http://www.res4med.org, 2015

8. MEMEE, 3eme communication nationale du Maroc a la Convention

Cadre des Nation Unies sur les Changements Climatiques. 2016. Rabat.

9. Dr. Abdelkader Amara, 'The role of solar power in mitigation strategies

in the MENA region: The Moroccan Solar Plan and its role in bridging

the nexus between climate and energy policies. COP 21 in Paris, 2015. Available from: http://www.mem.gov.ma/SiteAssets/Dicsours/Discours2015/Di scMLM2Dec15.pdf.

10. International Energy Agency, Morocco 2014: Energy policies beyond

IEA countries, 2014, Paris

11. Miriam Bardolet, Regulatory Overview Morocco. May 2014.

12. MEMEE. Regional integration strategic choice of Morocco: Strengthening and development of energy interconnection with neighboring coun-tries. Available from: http://www.mem.gov.ma/SitePages/CP2016/CP09Juin16.aspx, 2016.

13. Red Eléctrica de España, 2ème interconnexion électrique Espagne-Maroc. www.ree.es .

14. B. Mohamed, B. Assa, \& B. Ilhem. 'Electric network interconnection of Maghreb Arab countries'. In: Proceedings of 10 th international conference on environment and electrical engineering (EEEIC), Rome, Italy, 8-11 May 2011, 4 pp.

15. Feasibility Study on Morocco-Portugal Electric Interconnection Launched. https://www.moroccoworldnews.com, 2016.

16. ONEE, OUR SPECIALTIES. http://www.oneecop22.ma, 2016.
17. Z. Ettaik. 'Les énergies renouvelables au Maroc : Bilan et Perspectives'. Ministry of Energy, Mines, Water and the Environment (MEMEE), 2015.

18. Moroccan Agency for Solar Energy (MASEN). http://www.masen.ma/ar/projets/, 2017.

19. MENA-SELECT, Country Fact Sheet Morocco Energy and Development at a glance 2016. Available from: https://germanwatch.org/en/download/15121.pdf.

20. Moroccan-German Energy Partnership PAREMA, Renewable energy and energy efficiency in Morocco, http://dktimaroc.org, 2015.

21. T. Kousksou, A. Allouhi, M. Belattar, A. Jamil, T. El Rhafiki, A. Arid, \& Y. Zeraouli. 'Renewable energy potential and national policy directions for sustainable development in Morocco'. Renewable and Sustainable Energy Reviews, 47, 46-57, 2015.

22. Solar resource maps for Morocco: http://solargis.com/products/mapsand-gis data/free/download/morocco, 2017.

23. C. Richts. 'The Moroccan solar plan. A comparative analysis of CSP and PV utilization until 2020'. 2012.

24. Afilal ME, N. Belkhadir, Z. Merzak. 'Biogas production from anaerobic digestion of manure waste: Moroccan case'. Global J Sci Front Res 2013.

25. Agence Marocaine pour le Développements des Energies Renouvelables de l'Efficacité Energétique ; http://www.aderee.ma/.

26. A. Rimi, Y. Zarhloule, AE. Barkaoui, Correiac Antonio, J. Carneiro, M. Verdoya, F. Lucazeau. 'Towards a de-carbonized energy system in northeastern Morocco: prospective geothermal resource'. Renewable Sustainable Energy Rev, 16:220716, 2012.

27. JW. Lund, DH. Freeston, TL. Boyd. 'Direct utilization of geothermal energy worldwide review'. In: Proceedings world geothermal congress, Bali, Indonesia; April 2010.

28. K Choukri, A Naddami, S Hayani, Renewable energy in emergent countries: lessons from energy transition in Morocco. - Energy, Sustainability and Society, 2017 - Springer.

29. The Renewable Energy Sector in North Africa: Current Situation and Prospects, Published by the Subregional North Africa Office of the United Nations Economic Commission for Africa (UNECA), 2012.

30. N.Phuangpornpitak, S.Tia, Opportunities and challenges of integrating renewable energy in smart grid system, Energy Procedia, vol. 34, p. 282-290, 2013.

31. http://www.iresen.org/, 2017.

32. http://www.masen.ma/fr/, 2017.

33. http://www.amee.ma/index.php/fr/, 2017.

34. https://www.siem.ma/, 2017.

35. M.G.Kendall, \& J.K.Ord, Time-series, London: Edward Arnold, 1990.

36. Tournery, Jean-Francois, Pumped energy transfer stations (STEP). Encyclopédie de l'Energie, Grenoble INP - Ense3, Ecole Nationale Supérieure de l'Energie, l'Eau et l'Environnement, 2015. 